\title{
Dynamics of Proposition and Funding of Lecturers' Research Proposal at Private Universities in Higher Education Service Institutes Region XII - Indonesia
}

\author{
Ricardo Freedom Nanuru ${ }^{1}$, Mutiara Dara Utama ${ }^{2}$ \\ \{ricardonanuru632@gmail.com ${ }^{1}$, utamamutiaradara@gmail.com\}
}

Faculty of Theology, Universitas Halmahera - Tobelo, Indonesia ${ }^{1}$, Faculty of Social Science and Political Science, Universitas Kristen Indonesia Maluku - Ambon, Indonesia ${ }^{2}$

\begin{abstract}
The problem in this study was the gap between the target of the Indonesian Minister of Research, Technology and Higher Education (Menristekdikti) in the field of publication who wishes to be number one in ASEAN, meanwhile, the Higher Education Service Institute (LLDikti) Region XII of Maluku and North Maluku, which is one of the ministries' work units, has a number of lecturers who are not very active in the field of research with publication impact.This can be seen from the very small number of research proposals funded by the Directorate of Research and Community Service (DRPM) of Ministry of Research, Technology and Higher Education (Kemristekdikti) in the last 3 (three) years $(2017,2018$ and 2019). Speaking of which, the objective of this study was to find the inhibiting factors that underlie the lack of involvement of lecturers at private universities (PTS) in LLDikti XII.This type of research was a qualitative study that seeks to ideologically raise the phenomenon of the low level of proposition and the pass of lecturers' research proposals in LLDikti XII.The research site was overlapping with the the Higher Education Services Institute (LLDikti) Region XII, namely Maluku Province and North Maluku Province. Data were collected through document search, interviews, and focus group discussions. The analysis process was carried out both in the middle of and post data collection process. The steps to analyze the data were: (1) data reduction, (2) data "display", (3) understanding, interpretation, (4) drawing conclusions and verification. This study found that of 2,445 lecturers in LLDikti XII, the lecturers involved in the research did not reach a quarter of the total.Likewise with the number of Private Universities involved, which is from a total of 44 Private Universities, only one third participated in research funded by DRPM. This finding indicated that the average ability of lecturers (in this case also Private Universities) in LLDikti Region XII is still very limited and requires capacity building.
\end{abstract}

Keywords: Higher Education Service Institute; Indonesian Lecturer Publication; Indonesian Ministry of Research, Technology and Higher Education; Indonesian Lecturer.

\section{Introduction}

Publication is something that must be done to spread the results of scientific research so as to be known or used by academics and the public, in general. Publication is also a means to prove the existence of humans in public spaces in order to be recognized at the level of literacy and expertise culture [1]. The dynamics of the development of publications in Indonesia are growing rapidly along with the development of higher education, either in Indonesia or in other countries, especially in ASEAN. 
Based on data dated 8 April 2018, Scopus-indexed Indonesian publications in 2017 recorded 18,931 publications, 2 levels below Malaysia (31,006 publications) and Singapore (20,740 publications). Thankfully it's still above Thailand (15,651 publications), Viet Nam (6,391 publications), and the Philippines (3,150 publications). Based on data in the first half of 2018, in Scopus indexed international publications, Indonesia in the ASEAN region (only 2018 data) came in second with 5,163 publications, one level below Malaysia with 6,084 publications. The third position was occupied by Singapore with 5,062 publications and the fourth was Thailand with 3,800 publications. The fifth place was occupied by Viet Nam with 2,205 publications, and the sixth place was Philipines with 688 publications.[2].

The data changed rapidly as more data continued to enter reputable indexers, as uploaded by the Ministry of Research, Technology and Higher Education (Kemristekdikti) in the form of chart, on April 10, 2018, as presented below [3], [4]:

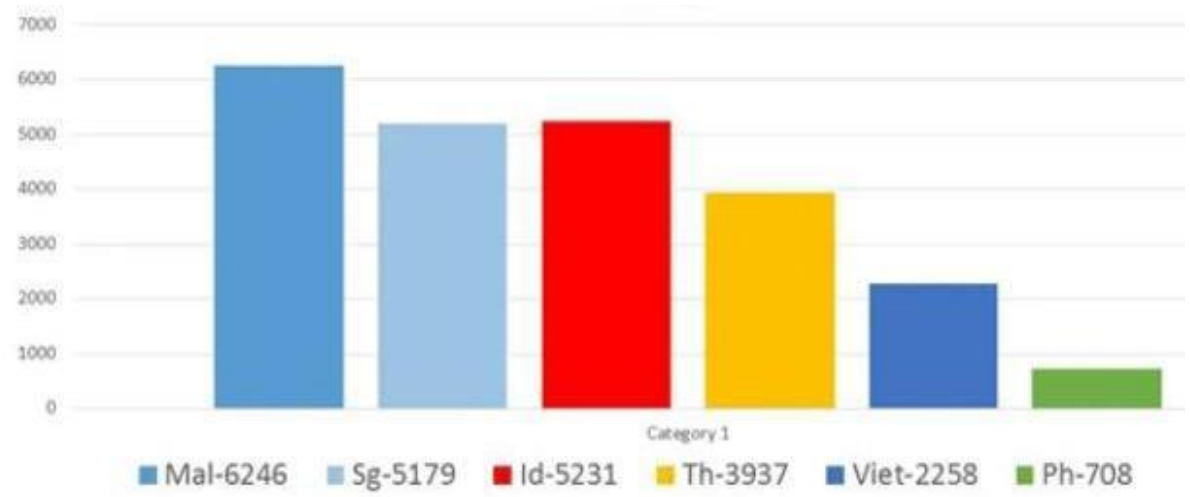

Fig. 1. International Publications of ASEAN countries indexed by global indexers 2018. Source of Data: Directorate General of Research and Development Ministry of Research, Technology and Higher Education (Kemristekdikti), April 10, 2018

Observing this dynamic, we should certainly be happy because what was targeted by the Minister of Research, Technology and Higher Education (Menristekdikti) that in 2019 the number of Indonesian publications must exceed 30,000 publications will be achieved successfully, given the large number of potential human resources in Indonesia, especially the functional positions of lecturers, researchers and doctoral program students who have obligations for international publication as requirements for promotion and graduation [5].

Responding to the struggle of Kemenristekdikti raised earlier, the important question now is: What is the contribution of the Higher Education Service Institute (LLDikti)Region XII in the spirit of publication on Kemenristekdikti? Based on the results of collaborative research entitled: "Factors Affecting the Research Productivity of Private University Lecturers in Kopertis Region XII Maluku and North Maluku" initiated by the writers and Jusuf Nikolas Anamofa, and involved 30 other researchers from 11 Private Universities in LLDikti Region XII, it appears that the biggest inhibiting factor is the lack of research and publication costs. The other inhibiting factors are the lack of information related to journals, reputable conferences, and the lack of networks between researchers, and inadequate availability of libraries.[6]

It is these things that are likely to make the number of research proposals funded in Simlitabmas from this region not to be too large. Recent data showed that research proposals funded by Ristekdikti were only 47 proposals (2017) [7], 64 proposals (2018) [8], and 139 
proposals [9], even the most is from the "learning" scheme,which is Novice Lecturer Research (PDP). When juxtaposed with the number of private universities (PTS), there are 44 PTS [10], then this number seems very small. Based on this background, the results of this study are important to support policy making and formulation of work programs related to research and publications among leaders either internally at PTS or at the LLDikti XII level.

\section{Method}

This type of research was a qualitative study that seeks to ideologically raise the phenomenon of the low level of proposition and the pass of lecturer research proposals at LLDikti XII.By raising this social phenomenon, it is expected that there will be answers that form a strong foundation for the formulation of policies and models for developing lecturer creativity in research and publications. [11].

The research sitewas overlapping with the Higher Education Services Institute (LLDikti) Region XII, namely Maluku Province and North Maluku Province. The research population was lecturers, Private University leaders, and officials within the LLDikti XII.The research sample was taken using the purposive method, namely lecturers who are recipients of research funds from the Directorate of Research and Community Service (DRPM), Ministry of Research, Technology and Higher Education (Kemenristekdikti) in the last 3 (three) years (2017, 2018, and 2019); lecturers who submitted proposals but have not passed in the last 3 (three) years (2017, 2018 and 2019); Heads of Research Institutions; PTS officials involved in research policies and lecturer publications; officials and employees in charge of research and lecturer publications at LLDikti XII.

The data were collected in several ways: (1) by searching documents related to the submission and approval of proposals through Simlitabmas Ristekdikti. This document data tracking involved announcement by DRPM through Simlitabmas, contracts between LLDikti XII (Kopertis Region XII) and PTS, as well as contracts between Lemlit/LPPM and lecturers. These data also concern all proposals submitted through the Simlitabmas database which can be seen from the data recorded by operators on each campus. This search was carried out both face to face and online (online survey) if it is not reachable through face to face. The data also concern the training activities of writing proposals and scientific articles for lecturers. (2) Interviews related to policies and work programs related to lecturers' research and publications. The interviewsare also to explore data related to policies on handling activities and funding as well as other matters relating to research and lecturer publications. (3) Focus Group Discussion (FGD), to explore data that has not been seen in document searches and interviews.

The analysis process was carried out in the middle of and even post data collection process. In connection with the large number of data that still needs to be determined in relation to one another, the classification of data according to the type and characteristics in accordance with the focus of research on the participation of lecturers in Ristekdikti research with publication outputs at the Higher Education Service Institute Region XII must be done.The steps to analyze the data were: (1) data reduction, (2) data "display", (3) understanding, and interpretation, (4) drawing conclusions and verification.

\section{Results}

Data for May 2019 showed that the number of Private Universities (PTS) in LLDikti XII Maluku and North Maluku was 44 with a total of 2,445 lecturers, divided into 781 
undergraduate (S1) levels, 1,526 people in Masters (S2), 76 people in Doctor (S3), and 62 peoplewithout the level(Higher Education Database (PD Dikti), 2019).

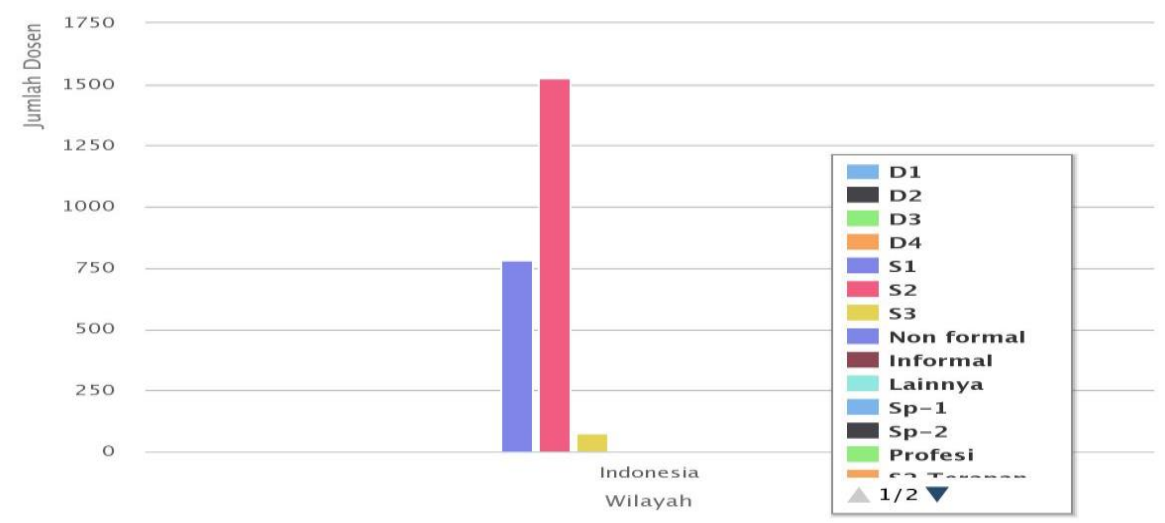

Fig. 2. Lecturer Data Distribution Based on Education Level in LLDikti Region XII Maluku and North Maluku. Source of Data: https://forlap.ristekdikti.go.id/dosen/homegraphjenjang.

A search of the SINTA portal showed that only 78 lecturers $(6 \%)$ of the total PTS lecturers were registered as verified authors. That number was only $0.10 \%$ compared to the total verified author on the SINTA portal which was 78,314 as of January 30, 2018. The number of Scopus-indexed publications was 11 or $0.02 \%$ of the total Scopus indexed publications on the SINTA portal, which was 59,132, consisting of 10 journal articles $(0.03 \%$ of 39,630$)$ and 1 conference paper $(0.01 \%$ of 16,533$)$, while the publication in the form of book chapters was not available.The number of publications uploaded on Google Scholar was 931 (0.11\% of 884,153).The data highlighed that: a) Private University Lecturers in the scope of LLDikti XII who are registered as verified authors on the SINTA portal were still very few; b) The research productivity of LLDikti XII Private University lecturers was still very little. This is inversely proportional to the expectation that lecturers can conduct research and publications as one of their main tasks.[6], [12].

Table 1. Research Productivity of Private University Lecturers (PTS) at the Higher Education Services Institute (LLDikti) XII of 2017 - 2019 Period. Source of Data: Processed from the research results ${ }^{1}$

\begin{tabular}{ccccccc}
\hline No & Year & $\begin{array}{c}\text { Number of } \\
\text { Funded Proposals }\end{array}$ & $\begin{array}{c}\text { Number of } \\
\text { PTS Involved }\end{array}$ & Schemes & $\begin{array}{c}\text { Number of } \\
\text { Schemes }\end{array}$ & \% \\
\hline $\mathbf{1}$ & 2017 & 49 & 13 & PDP & 34 & $\mathbf{7 0 . 8}$ \\
& & & PPT & 6 & $\mathbf{1 2 . 5}$ \\
& & & PDD & 6 & $\mathbf{1 2 . 5}$ \\
& & & & PEKERTI & 3 & $\mathbf{4 . 2}$ \\
\hline $\mathbf{2}$ & 2018 & 65 & 16 & PDP & 51 & $\mathbf{7 8 . 5}$ \\
& & & & PPT & 2 & $\mathbf{3 . 1}$ \\
& & & PDD & 8 & $\mathbf{1 2 . 2}$ \\
& & & PPD & 2 & $\mathbf{3 . 1}$ \\
& & & & PEKERTI & 2 & $\mathbf{3 . 1}$ \\
\hline
\end{tabular}

\footnotetext{
${ }^{1}$ The main data in this table is taken from the recapitulation of funding proposals for the last 3 years sourced from the Field of Research in Higher Education Service Institutes (LLDikti) Region XII, Maluku and North Maluku, as well as the results of data searches at research Institutes in Private Universities (PTS).
} 


\begin{tabular}{lccccc}
\hline 3 & & & & \\
& 139 & 16 & PDP & 131 & $\mathbf{9 4 . 2}$ \\
& & PPD & 1 & $\mathbf{0 . 7}$ \\
& & PD & 3 & $\mathbf{2 . 2}$ \\
& & PPT & 1 & $\mathbf{0 . 7}$ \\
& & PEKERTI & 3 & $\mathbf{2 . 2}$ \\
\hline
\end{tabular}

Based on the Research Productivity table of Private University Lecturers (PTS) at the Higher Education Services Institute (LLDikti) XII for the period of 2017 - 2019 above, it can be seen that in 2017 the number of proposals funded was 48 from only 13 PTS (29.5) percent) from a total of 44 PTS.The data also showed that of the 17 schemes offered in research funded by the Directorate of Research and Community Service (DRPM) of the Ministry of Research and Higher Education,only 4 schemes succeeded in getting funding, which were 34 proposals (70.8 percent) of Novice Lecturer Research (PDP), 6 proposals (12.5 percent) of Applied Product Research (PPT), 6 proposals (12.5 percent) of Doctoral Dissertation Research (PDD), and 3 proposals (4.2 percent) of Collaborative Research between Universities (PEKERTI).

Meanwhile, in 2018 the number of proposals funded increased from 48 proposals to 65 proposals whose origins also increased which were from 13 PTS to 16 PTS (36.4 percent) from a total of 44 PTS. The data also indicated that from the 14 schemes offered in research funded by the Directorate of Research and Community Service (DRPM) of the Ministry of Research and Higher Education, it appears that only 5 schemes had succeeded in obtaining funding,such as 51 proposals (78.5 percent) of Novice Lecturer Research (PDP), 2 proposals (3.1 percent) of Applied Product Research (PPT), 8 proposals (12.2 percent) of Doctoral Dissertation Research (PDD), 2 proposals (3.1 percent) of Post-Doctoral Research ( PDD), and 2 proposals (3.1 percent) of Collaborative Research between Universities (PEKERTI).

In 2019, the number of proposals funded increased significantly from 65 proposals to 139 proposals but the distribution of proposals remains the same, which is from 16 PTS (36.4 percent) out of a total of 44 PTS.The data also show that of the 12 schemes offered in research funded by the Directorate of Research and Community Service (DRPM) of Ministry of Research and Higher Education, it appears that only 5 schemes have succeeded in getting funding, such as 131 proposals (94.2 percent) of Novice Lecturer Research (PDP), 1 proposal (0.7 percent) of Post Doctoral Research (PDD), 3 proposals (2.2 percent) of Basic Research (PD), 1 proposal (0.7 percent) of Applied Product Research (PPT), and 3 proposals (2.2 percent) of Collaborative Research between Universities (PEKERTI).

\section{Discussion}

Based on the data in the table 1, it can be concluded that the involvement of PTS lecturers in the LLDikti region XII in research funded by DRPM was still very minimal and alarming. The total number of proposals passed in 2017 was 49 assuming the average lecturer involved was 2 people per proposal, so the total number of lecturers involved was 98 lecturers. This number is very small, which was 4.01 percent compared to the total number of lecturers under LLDikti Region XII, which is 2,441 permanent lecturers recorded in the Kemenristekdikti database. This data increased slightly in 2018, where there were 65 proposals passed or it could be assumed that 130 lecturers were involved in the research.This data was equivalent to 5.32 percent of the total number of lecturers at LLDikti XII. 2019 is a year with significant progress because the funded proposal data has more than doubled, with 139 proposals successfully funded and around 278 lecturers involved in conducting research. This number is equivalent to 11.37 percent of the total permanent lecturers of PTS in LLDikti XII.

There are several factors related to research activities and productivity. This is evident in the findings of several previous studies, such as: a) motivation to research and write [13]; b) 
Psychological character, work culture, age, work environment productivity, and institutional prestige [14]; c) Individual and institutional factors[15]; d) Inadequate research funding, university environment which hinders the development of research, regulations on procurement of goods and services that limit university participation in government-sponsored research [16].

Another thing that affects the productivity of lecturer research at LLDikti XII is the lack of knowledge of lecturers related to research funded by DRPM Ristekdikti. In other words, the socialization related to research by DRPM Ristekdikti did not go well.Indeed, for the purpose of socialization, DRPM Ristekdikti has created a research system and community service portal (Simlitabmas), but this website page is only accessed by lecturers who have a level of technological expertise categorized good.On the other hand, lecturers who are not familiar with technology like this tend to be apathetic and seem to avoid conducting research funded by DRPM and conduct research using independent funds or PTS internal funds. ${ }^{2}$

Another inhibiting factor that makes lecturers reluctant to get involved in research with DRPM Ristekdiktifunds is their lack of knowledge related to elements of the substance of the research proposal (research gap, novelty, identification research contribution, managerial implication, roadmap, etc.) which causes them to somewhat feeling hard to make a proposal.The weak involvement of lecturers in the substance of the proposal is also strengthened by their lack of knowledge related to administrative requirements supporting the proposal, such as the number of reputable international publications (indexed by Scopus and Web of Science), H Index (issued by Scopus and Web of Science), SINTA account ownership, synchronization between data in Dikti and Simlitabmas information system, and so on.[17]

In addition to the factors above, other inhibiting factor that causes the lecturers to be reluctant to propose research proposals are internal factor from the lecturer itself, which is the lack of knowledge related to financial information and guidance on the Minister of Finance Regulation (PMK).The lack of knowledge has an impact on lecturer skills related to the preparation of research proposal budget based on Output Cost Standard (SBK) and Input Cost Standard (SBM) in the Minister of Finance Regulation (PMK). The lack of knowledge and skills in preparing the proposal budget by the lecturer is due to the absence of socialization, either by the DRPM Ristekdikti or LLDikti, or the Private Universities where these lecturers are located.The related institutions above seem to have concluded that the lecturers already have the ability to prepare research budgets that are guided by PMK and have never carried out socialization to them.Another factor related to this financial issue is that the lecturers seem afraid to deal with the Supreme Audit Agency (BPK) if there is a report on their financial accountability that is problematic because the research carried out is based on input, which is examined up to the detail of expenditure receipts. ${ }^{3}$

Based on the results of the research that has been done, it can be seen that from 44 Private Universities (PTS) in the Higher Education Services Institute (LLDikti) Region XII, only 4 (four) PTS have actually allocated and proven to provide internal research funding to lecturers.In the work program, each PTS allocates research funds according to the program, but only 4 PTS makes it happen. The funds are absorbed in the lecturer independent research

${ }^{2}$ Interview results with: Head of the Research and Community Service Institute (LPPM), Maluku Husada College of Health Sciences, Kairatu - Indonesia; Secretary of the Institute for Research and Community Service (LPPM) Sekolah Tinggi Keguruan dan Ilmu Pendidikan, Masohi - Indonesia; Kepala LPPM Universitas Pasifik, Morotai - Indonesia. Sekretaris Lembaga Penelitian Universitas Kristen Indonesia Maluku, Ambon - Indonesia.

${ }^{3}$ Interview result with: Head of the Research and Community Service Institutes (LPPM) Banau School of Entrepreneurship, Jailolo - Indonesia. 
program, lecturer and student research, excellent research, and research with other scheme names.Allocation of funds is also intended for research methodology training activities, preparation of proposals, to the training of research support staff.But in 38 out of 44 PTS, the allocation of these work programs could not be realized because averagely, the PTS in the LLDikti Region XII had problems in terms of financial management, causing an imbalance in program funding. Priority for PTS funding is routine activities and salary for lecturers, so that research and devotion of lecturers do not run as programmed. ${ }^{4}$

Based on the exposure of various data above, serious treatment is needed from DRPM Ristekdikti, LLDikti XII, PTS, and other stakeholders related to the development of higher education in this region. Scientific publication is an important part of the research process.By publishing, research findings can be known by fellow researchers in their fields in particular and the community in general. Researchers can also make theoretical and practical contributions in the field of human life, not solely for the sake of pursuing a career as a scientist.Publication is the center of activity of the scientific community that has an impact on scientific progress, either related to results, methods, standards, or scientific principles [18]. There are three roles of scientific publication in the process of scientific communication, such as the social role to build and maintain intellectual property so that the work of researchers can get recognition from the world of related disciplines; the role of archives as the effort to document scientific work that has been evaluated and accepted by the world of science; and the role of dissemination as the effort to disseminate scientific ideas in the perspective of scientific accumulation.[19]. In addition, if the researcher is a teacher or lecturer, scientific publication becomes the main requirement for the promotion of functional rank.[20], [21].

\section{Conclusion}

This study found that the involvement of lecturers in research activities funded by the Directorate of Research and Community Service (DRPM) of Higher Education (Dikti) is still very small compared to the number of permanent lecturers serving in Private Universities (PTS) in the Higher Education Service Institutes (LLDikti) Region XII. The inhibiting factors for the involvement of lecturers in research funded by DRPM are also new findings compared to the findings of previous studies. Here, lecturers tend not to research because they are "frightened" by the accountability system of research results that are very administrative, which tend to be burdensome, and that turn lecturers into administrative staff rather than researchers.Another frightening thing is the financial reporting system which seems burdensome and can result in refunds that have been used to the state treasury if there is an error in the preparation of a budget plan and research expenditure that is not in accordance with applicable regulations.In recent years (2018 and 2019), this has been minimized by DRPM by implementing output-based research, but the resonance needs to be echoed more for lecturers.

\section{Acknowledgment}

Acknowledgments are conveyed respectively, to:

1. Directorate of Research and Community Service (DRPM) Ministry of Research, Technology and Higher Education (Kemristekdikti) which has funded this research in its first year

${ }^{4}$ Findings during the field research process with in-depth interviews with resource persons from all Heads of Research Institutions. 
2. Higher Education Service Institutes (LLDikti) Region XII, Maluku and North Maluku that have facilitated research permits in their working region.

3. All Private Universities (PTS) that have participated provide data for the smooth running of this research.

\section{References}

[1] R. F. Nanuru, "Sasadu: The Religious Social Spirit of Sahu Tribe Community in North Maluku - Indonesia," J. Soc. Sci. Res., vol. 5, no. 4, pp. 1274-1283, 2019.

[2] Dasapta Erwin Irawan, "Data Jumlah Publikasi 6 Negara ASEAN Menurut Scopus," 2018. .

[3] R. T. Utami, "Geser Singapura dan Thailand, Publikasi Ilmiah Indonesia Peringkat ke-2 ASEAN," Mina News, Bogor, Apr-2018.

[4] Dhita Setiawan, "Akhirnya Lampaui Singapura, Publikasi Ilmiah Indonesia ke-2 ASEAN," Pikiran Rakrat, Jakarta, Apr-2018.

[5] R. F. Nanuru, "Menyikapi Lemahnya Geliat Publikasi Ilmiah Di Kopertis Wilayah Xii, Maluku dan Maluku Utara." 03-May-2018.

[6] Jusuf Nikolas Anamofa, Ricardo Freedom Nanuru, Maya Laisila, and T. D. Cahyono, "Faktor-Faktor Yang Mempengaruhi Produktivitas Penelitian Dosen Perguruan Tinggi Swasta Di Kopertis Wilayah XII Maluku dan Maluku Utara," in The 1st International Conference On Advance \& Scientific Innovation - ICASI 2018, 2018.

[7] Ocky Karna Rajasa, "Lampiran Surat No: 025/E3/2017 Tanggal 6 Januari 2017 Tentang Penerima Pendanaan Penelitian dan Pengabdian Masyarakat di Perguruan Tinggi Tahun 2017," Jakarta, 2017.

[8] Ocky Karna Rajasa, "Lampiran Surat Nomor: 0045/E3/LL/2018 Tanggal 16 Januari 2018 Tentang Penerimaan Pendanaan Penelitian dan Pengabdian Masyarakat di Perguruan Tinggi Tahun 2018," Jakarta, 2018.

[9] Ocky Karna Rajasa, "Lampiran Surat Nomor: T/140/E3/RA.00/2019, Tanggal 25 Februari 2019 Penerima Pendanaan Penelitian dan Pengabdian kepada Masyarakat di Perguruan Tinggi Tahun 2019 (Lampiran 1. Penerima pendanaan penelitian di Perguruan Tinggi non PTNBH)," Jakarta, 2019.

[10] Pangkalan Data Pendidikan Tinggi (PD Dikti), "Sebaran Data Dosen Berdasarkan Tingkat Pendidikan di LLDikti Wilayah XII Maluku dan Maluku Utara," Kementerian Riset, Teknologi dan Pendidikan Tinggi, 2019. .

[11] G. R. Somantri, "Memahami Metode Kualitatif," Makara Sos. Hum., vol. 9, no. 2, pp. 57-65, 2005.

[12] Jusuf Nikolas Anamofa and Ricardo Freedom Nanuru, "Analysis of Scopus - Indexed Scientific Publication of Lecturers in Maluku on SINTA Portal," in Proceedings of Workshop on Multidisciplinary and Application - WMA 2017, 2017.

[13] Zain S. M, "Motivation for research and publication: Experience as a researcher and an academic," in Procedia - Social and Behavioral Sciences, 2011, pp. 213-219.

[14] Fox M.F, "Publication Productivity among Scientists: A Critical Review," Soc. Stud. Sci., vol. 13, no. 2, pp. 285-305, 1983.

[15] Fawsi H and Al-Hattami H, "Faculty Production of Research Papers: Challenges and Recommendations," Int. J. Humanit. Soc. Sci., vol. 7, no. 2, pp. 221-228, 2017.

[16] Yanuar Nugroho, Budiati Prasetiamartati, and Siti Ruhanawati, "Mengatasi Hambatan Penelitian di Universitas," Jakarta, 2016.

[17] F. Gerit et al., "Management Information System for Monitoring and Inspection of the Implementation of Universities," vol. 7, pp. 451-456, 2018. 
[18] National Research Council, Sharing Publication-Related Data and Materials: Responsibilities of Authorship in The Life Sciences. Washington DC: The National Academies Press, 2003.

[19] Tupan, "Analisis Karya Ilmiah Peneliti LIPI Pada Jurnal Internasional ScienceDirect," Visi Pustaka, vol. 17, no. 1, pp. 20-32, 2015.

[20] Direktorat Jenderal Guru dan Tenaga Kependidikan, Buku 4: Pedoman Kegiatan Pengembangan Keprofesian Berkelanjutan Bagi Guru Pembelajar. Jakarta: Kementerian Pendidikan dan Kebudayaan, 2016.

[21] Lukman and dkk, Pedoman Publikasi Ilmiah. Jakarta: Direktorat Pengelolaan Kekayaan Intelektual Direktorat Jenderal Penguatan Riset dan Pengembangan Kementerian Riset, Teknologi, dan Pendidikan Tinggi, 2017. 